University of Nebraska - Lincoln

DigitalCommons@University of Nebraska - Lincoln

5-15-2003

\title{
Structure and magnetic properties of sputtered hard/soft multilayer magnets
}

W. Liu

Shenyang National Laboratory for Materials Science and International Centre for Materials Physics, Institute of Metal Research, Chinese Academy of Sciences, Shenyang 110016, People's Republic of China

Z.D. Zhang

Shenyang National Laboratory for Materials Science and International Centre for Materials Physics, Institute of Metal Research, Chinese Academy of Sciences, Shenyang 110016, People's Republic of China

J. Ping Liu

University of Nebraska-Lincoln, pliu@uta.edu

B.Z. Cui

Shenyang National Laboratory for Materials Science and International Center for Materials Physics, Institute of Metal Research, Chinese Academy of Sciences, Shenyang 110016, People's Republic of China

X.K. Sun

Shenyang National Laboratory for Materials Science and International Center for Materials Physics, Institute of Metal Research, Chinese Academy of Sciences, Shenyang 110016, People's Republic of China

See next page for additional authors

Follow this and additional works at: https://digitalcommons.unl.edu/physicssellmyer

Part of the Physics Commons

Liu, W.; Zhang, Z.D.; Liu, J. Ping; Cui, B.Z.; Sun, X.K.; Zhou, J.; and Sellmyer, David J., "Structure and magnetic properties of sputtered hard/soft multilayer magnets" (2003). David Sellmyer Publications. 33. https://digitalcommons.unl.edu/physicssellmyer/33

This Article is brought to you for free and open access by the Research Papers in Physics and Astronomy at DigitalCommons@University of Nebraska - Lincoln. It has been accepted for inclusion in David Sellmyer Publications by an authorized administrator of DigitalCommons@University of Nebraska - Lincoln. 


\section{Authors}

W. Liu, Z.D. Zhang, J. Ping Liu, B.Z. Cui, X.K. Sun, J. Zhou, and David J. Sellmyer 


\title{
Structure and magnetic properties of sputtered hard/soft multilayer magnets
}

\author{
W. Liu ${ }^{\text {a) }}$ and Z. D. Zhang \\ Shenyang National Laboratory for Materials Science and International Centre for Materials Physics, \\ Institute of Metal Research, Chinese Academy of Sciences, Shenyang 110016, People's Republic of China \\ J. P. Liu ${ }^{\text {b) }}$ \\ Center for Materials Research and Analysis, University of Nebraska, Lincoln, Nebraska 68588-0113 \\ B. Z. Cui and X. K. Sun \\ Shenyang National Laboratory for Materials Science and International Center for Materials Physics, \\ Institute of Metal Research, Chinese Academy of Sciences, Shenyang 110016, People's Republic of China \\ J. Zhou and D. J. Sellmyer \\ Center for Materials Research and Analysis, University of Nebraska, Lincoln, Nebraska 68588-0113
}

(Presented on 14 November 2002)

\begin{abstract}
The films with $\mathrm{HM}=(\mathrm{Pr}, \mathrm{Dy})(\mathrm{Fe}, \mathrm{Co}, \mathrm{Nb}, \mathrm{B})_{5.5}$ and $\mathrm{SM}=\mathrm{Fe}, \mathrm{FeCo}$ were prepared by sputtering and subsequent heat treatment. The coercivity of Ti-buffered $(\mathrm{Pr}, \mathrm{Dy})(\mathrm{Fe}, \mathrm{Co}, \mathrm{Nb}, \mathrm{B})_{5.5}$ single-layer film with $320 \mathrm{~nm}$ thickness is as large as $18.8 \mathrm{kOe}$ at room temperature. X-ray diffraction results reveal that the $\operatorname{Pr}_{2} \mathrm{Fe}_{14} \mathrm{~B}$-type phase is randomly oriented in almost all the multilayer films. For the multilayers of $\operatorname{Ti}(30 \mathrm{~nm}) /[\mathrm{HM}(16 \mathrm{~nm}) \mathrm{Fe}(x \mathrm{~nm})] \times 20 / \mathrm{Ti}(30 \mathrm{~nm}) / \mathrm{Si}($ substrate $)$, the remanence increases and the coercivity decreases with the addition of Fe content, in comparison with the results of the single-layer film and the maximum energy product of 14.8 MGOe is obtained at $x=3.0$. A noticeable shoulder on the demagnetization curve is observed at low temperatures. When $\mathrm{Fe}_{65} \mathrm{Co}_{35}$ is used as the SM component rather than Fe, similar results are found. The enhancement of the magnetic properties in the nanocomposite multilayer films is explained by means of the exchange coupling between the SM and/or HM nanograins of the intra- and interlayers. (C) 2003 American Institute of Physics. [DOI: 10.1063/1.1558663]
\end{abstract}

\section{INTRODUCTION}

Recently, some studies on the exchange coupling were carried out for nanostructured $\mathrm{CoSm} / \mathrm{FeCo}$ and $\mathrm{PrCo} / \mathrm{Co}$ multilayers prepared by sputtering and subsequent heat treatment. ${ }^{1,2}$ Magnetic properties of exchange-coupled $\alpha$-Fe/ $\mathrm{Nd}-\mathrm{Fe}-\mathrm{B}$ multilayer magnets were investigated by Shindo and Ishizone ${ }^{3}$ and the observations for $\mathrm{Nd}-\mathrm{Fe}-\mathrm{B} / \mathrm{Fe} / \mathrm{Nd}-$ $\mathrm{Fe}-\mathrm{B}$ trilayers were reported by Parhofer et $_{\text {al }}{ }^{4,5}$ and Yang et $a l .{ }^{3,6}$ In our recent work, ${ }^{7}$ we investigated the magnetic properties of nanocomposite multilayer magnets of (Nd,Dy) $(\mathrm{Fe}, \mathrm{Co}, \mathrm{Nb}, \mathrm{B})_{5.5} / \mathrm{M}\left(\mathrm{M}=\mathrm{Co}, \mathrm{Fe}_{65} \mathrm{Co}_{35}\right)$ multilayer on Ti-buffered Si substrates prepared by sputtering and subsequent heat treatments. In comparison with the case of the single layer, the remanence of the multilayer magnets increases noticeably. Although the behavior at room temperature of the Pr-based $\mathrm{R}_{2} \mathrm{Fe}_{14} \mathrm{~B}$-type alloy is somewhat similar to that of the Nd-based counterpart, the former is still distinctive from the latter, which stimulates us to study the structural and magnetic properties of nanocomposite ( $\mathrm{Pr}, \mathrm{Dy})(\mathrm{Fe}, \mathrm{Co}, \mathrm{Nb}, \mathrm{B})_{5.5} /\left(\mathrm{Fe}\right.$ or $\left.\mathrm{Fe}_{65} \mathrm{Co}_{35}\right)$ multilayer magnets synthesized by sputtering and subsequent annealing.

\footnotetext{
a) Author to whom correspondence should be addressed; also at: Center for Materials Research and Analysis, University of Nebraska, Lincoln, NE 68588-0113; electronic mail: w.liu@imr.ac.cn

b) Also at: Institute for Micromanufacturing, Louisiana Tech University, Ruston, LA 71272.
}

\section{EXPERIMENT}

(Pr,Dy) $(\mathrm{Fe}, \mathrm{Co}, \mathrm{Nb}, \mathrm{B})_{5.5} / \mathrm{Fe} \quad\left(\right.$ or $\mathrm{Fe}_{65} \mathrm{Co}_{35}$ ) thin films were prepared with a multiple-gun dc- and rf-sputtering system by depositing the hard magnetic (HM) $\left(\mathrm{Pr}_{0.9} \mathrm{Dy}_{0.1}\right)\left(\mathrm{Fe}_{0.77} \mathrm{Co}_{0.12} \mathrm{Nb}_{0.03} \mathrm{~B}_{0.08}\right)_{5.5}$ alloy and the soft magnetic (SM) Fe or $\mathrm{Fe}_{65} \mathrm{Co}_{35}$ targets onto silicon substrate, covered with a $30 \mathrm{~nm}$ Ti buffer. The alloy targets were homemade by sintering powdered compacts and others were commercial products. Purities of all the targets were higher than $99.9 \%$. The base pressure of the sputtering system was $2-3 \times 10^{-7}$ Torr, and the Ar pressure during the sputtering was $5 \times 10^{-3}$ Torr. The thickness of the films was measured by weighing the mass of the films. The as-deposited films were annealed in a furnace with a vacuum of 2 $\times 10^{-7}$ Torr. The crystalline structure of the phases in the films was identified by x-ray diffraction (XRD) with $\mathrm{Cu} K \alpha$ radiation. Magnetic properties of the films were measured by an alternating gradient force magnetometer and a superconducting quantum interference device magnetometer. The hysteresis loops, as well as the values for the magnetic properties, were recorded without the demagnetizing correction.

\section{RESULTS AND DISCUSSION}

For comparison with the results of multilayers, initially, a hard phase single-layer film with composition of Ti (30 $\mathrm{nm}) / \mathrm{HM}(320 \mathrm{~nm}) / \mathrm{Ti}(30 \mathrm{~nm}) /($ Si substrate $)$ was investigated. 


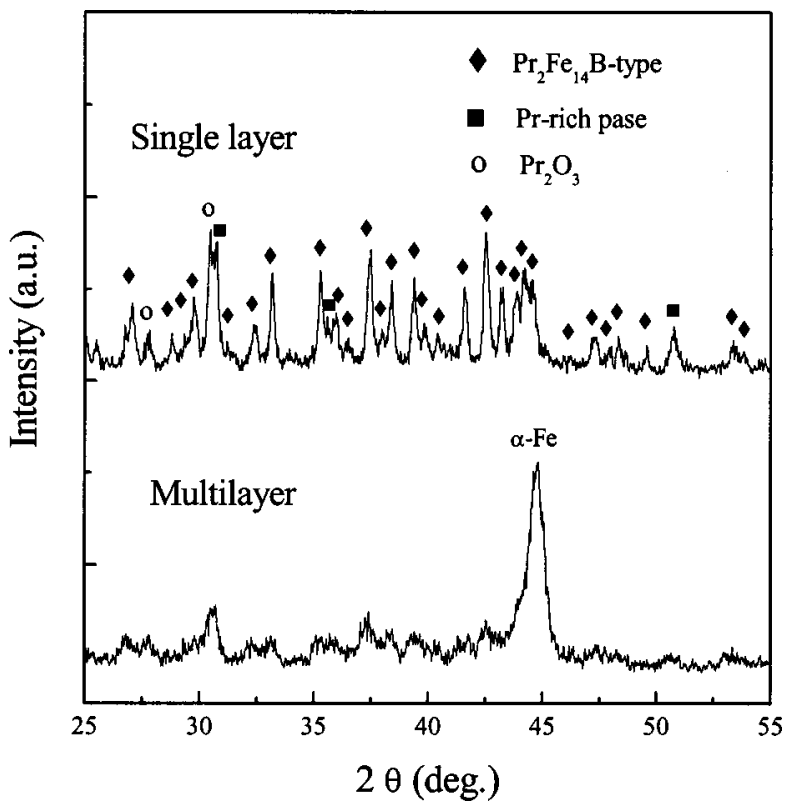

FIG. 1. XRD patterns for the Ti $(30 \mathrm{~nm}) / \mathrm{HM}(320 \mathrm{~nm}) / \mathrm{Ti}(30 \mathrm{~nm}) /(\mathrm{Si}$ substrate) single layer and $\mathrm{Ti}(30 \mathrm{~nm}) /[\mathrm{HM}(16 \mathrm{~nm}) \mathrm{Fe}(9 \mathrm{~nm})] \times 20 / \mathrm{Ti}(30 \mathrm{~nm}) /(\mathrm{Si}$ substrate) multilayer films annealed at $600{ }^{\circ} \mathrm{C}$ for $5 \mathrm{~min}$.

Similar to the case of $(\mathrm{Nd}, \mathrm{Dy})(\mathrm{Fe}, \mathrm{Co}, \mathrm{Nb}, \mathrm{B})_{5.5}$ single-layer films, ${ }^{7}$ the as-deposited $(\mathrm{Pr}, \mathrm{Dy})(\mathrm{Fe}, \mathrm{Co}, \mathrm{Nb}, \mathrm{B})_{5.5}$ single-layer films are amorphous. After annealing at $600{ }^{\circ} \mathrm{C}$ for $5 \mathrm{~min}$, the main phase of the films is of $\mathrm{Pr}_{2} \mathrm{Fe}_{14} \mathrm{~B}$ type, accompanied by a Pr-rich phase and some $\mathrm{Pr}_{2} \mathrm{O}_{3}$. XRD patterns for the Ti(30 $\mathrm{nm}) / \mathrm{HM}(320 \mathrm{~nm}) / \mathrm{Ti}(30 \mathrm{~nm}) /($ Si substrate $)$ single-layer film and $\mathrm{Ti}(30 \mathrm{~nm}) /[\mathrm{HM}(16 \mathrm{~nm}) \mathrm{Fe}(9 \mathrm{~nm})] \times 20 / \mathrm{Ti}(30 \mathrm{~nm}) /(\mathrm{Si}$ substrate) multilayer film annealed at $600{ }^{\circ} \mathrm{C}$ for $5 \mathrm{~min}$ are shown in Fig. 1. In comparison with the result of the singlelayer film, it is clear that adding a $10 \mathrm{~nm}$ thick Fe layer in the system with a $16 \mathrm{~nm}$ thick hard-phase layer results in the appearance of a large amount of $\alpha$-Fe and the disappearance of the Pr-rich phase in the sample after annealing. Almost all of the XRD peaks of the films correspond to randomly oriented $\mathrm{Pr}_{2} \mathrm{Fe}_{14} \mathrm{~B}$-type phase, except for $\alpha$-Fe.

Figure 2 gives hysteresis loops at room temperature for the single-layer and multilayer films, whose structures are shown in Fig. 1. The magnetic properties of ${ }_{J} H_{c}$ $=18.8 \mathrm{kOe}, 4 \pi M_{r}=6.1 \mathrm{kG}$, and $(B H)_{\max }=8.5 \mathrm{MGOe}$ are achieved for the single-layer film. For the Ti(30 nm)/[HM(16 $\mathrm{nm}) \mathrm{Fe}(9 \mathrm{~nm})] \times 20 / \operatorname{Ti}(30 \mathrm{~nm}) /(\mathrm{Si}$ substrate $)$ multilayer film, although the coercivity decreases, the remanence is enhanced greatly due to the effective exchange coupling between the nanograins of SM and HM phases in the multilayer film.

To understand the effect of the thickness of the Fe layer, the magnetic properties at room temperature of the thin films of $\mathrm{Ti}(30 \mathrm{~nm}) /[\mathrm{HM}(16 \mathrm{~nm}) \mathrm{Fe}(x \mathrm{~nm})] \times 20 / \mathrm{Ti}(30 \mathrm{~nm}) /$ (Si substrate) multilayers annealed at $600^{\circ} \mathrm{C}$ for $5 \mathrm{~min}$ are given in Fig. 3. Compared to the result of the single-layer film $(x=0)$, by increasing the thickness of the Fe layer, the intrinsic coercivity decreases, the remanence increases clearly, and the energy products reach the maximum of 14.8 MGOe for $x=3$.

Figure 4 shows a hysteresis loop at room temperature and a demagnetization curve at $10 \mathrm{~K}$ for $\mathrm{Ti}(30 \mathrm{~nm}) /[\mathrm{HM}(13$

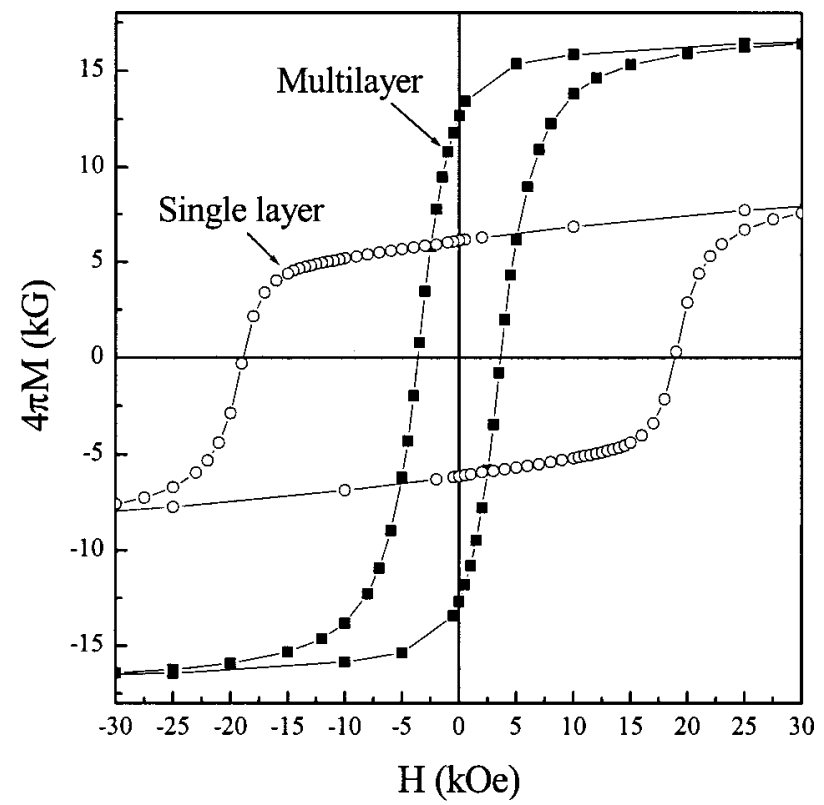

FIG. 2. Hysteresis loops at room temperature for the single layer and multilayer films shown in Fig. 1.

$\mathrm{nm}) \mathrm{Fe}(5 \mathrm{~nm})] \times 20 / \mathrm{Ti}(30 \mathrm{~nm}) /(\mathrm{Si}$ substrate $)$ multilayer film annealed at $625^{\circ} \mathrm{C}$ for $1 \mathrm{~min}$. The magnetic properties, $4 \pi M_{r}=9.5 \mathrm{kG},{ }_{J} H_{c}=9.9 \mathrm{kOe}$, and $(B H)_{\max }=14.7 \mathrm{MGOe}$ are achieved in the multilayer film at room temperature. In comparison with the result of the single-layer film mentioned herein, the remanence and the maximum energy product increase clearly due to the exchange coupling between the SM and/or HM nanograins of the intra- and interlayers. Coercivity up to $37.7 \mathrm{kOe}$ is observed when measured at $10 \mathrm{~K}$ for $\mathrm{Ti}(30 \mathrm{~nm}) /[\mathrm{HM}(13 \mathrm{~nm}) \mathrm{Fe}(5 \mathrm{~nm})] \times 20 / \mathrm{Ti}(30 \mathrm{~nm}) /(\mathrm{Si}$ substrate). However, a noticeable shoulder on the demagnetiza-

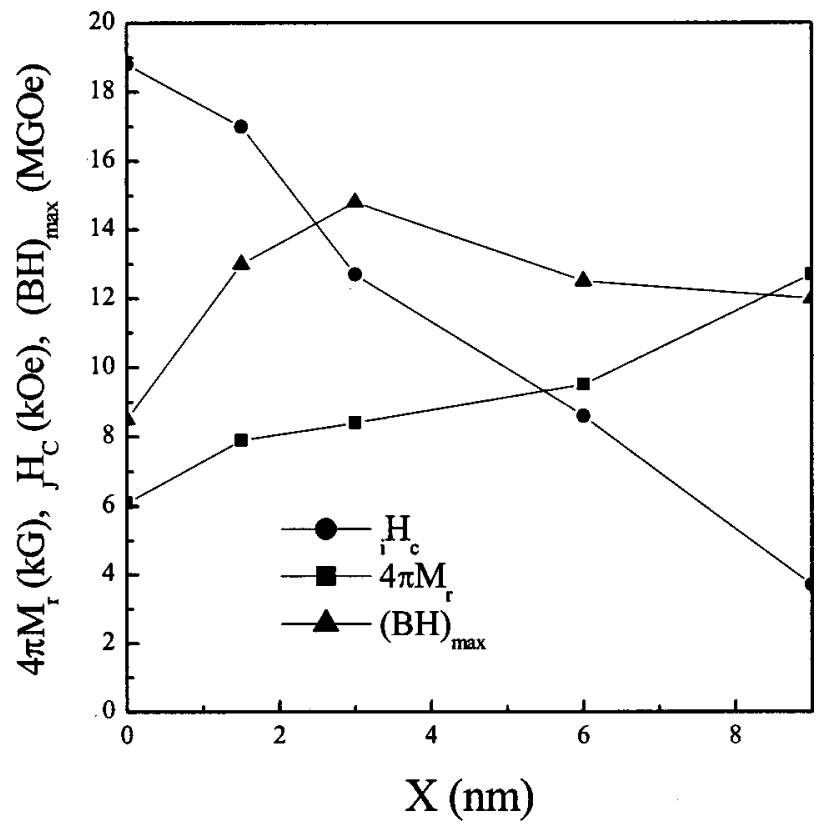

FIG. 3. Magnetic properties at room temperature of the thin films of $\mathrm{Ti}(30 \mathrm{~nm}) /[\mathrm{HM}(16 \mathrm{~nm}) \mathrm{Fe}(x \mathrm{~nm})] \times 20 / \mathrm{Ti}(30 \mathrm{~nm}) /(\mathrm{Si}$ substrate $)$ multilayer films annealed at $600^{\circ} \mathrm{C}$ for $5 \mathrm{~min}$. 


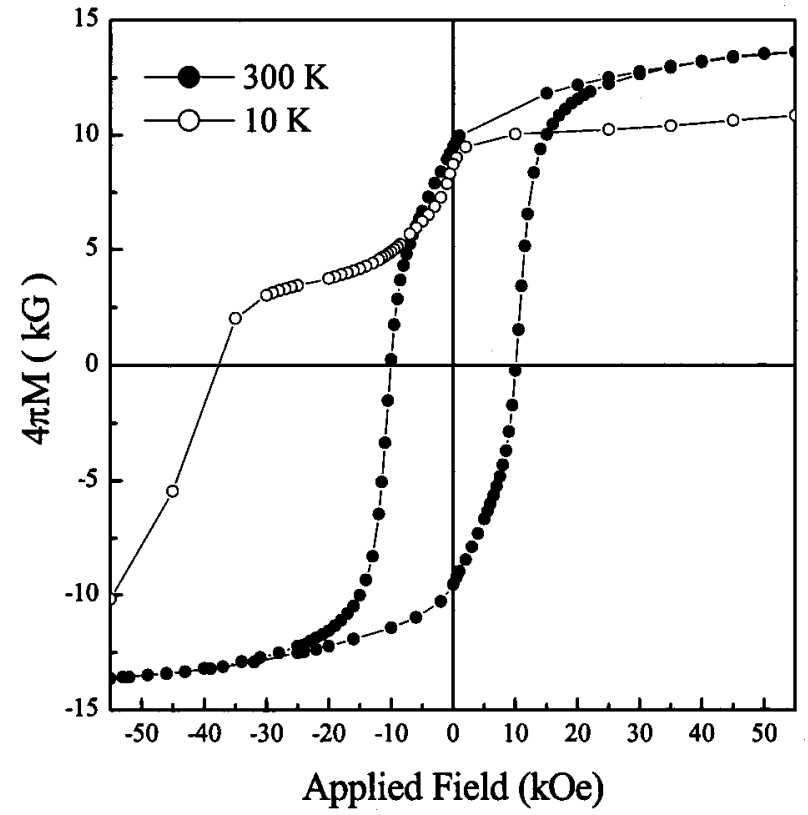

FIG. 4. Hysteresis loop at room temperature and demagnetization curve at $10 \mathrm{~K}$ for $\mathrm{Ti}(30 \mathrm{~nm}) /[\mathrm{HM}(13 \mathrm{~nm}) \mathrm{Fe}(5 \mathrm{~nm})] \times 20 / \mathrm{Ti}(30 \mathrm{~nm}) /(\mathrm{Si}$ substrate $)$ multilayer film annealed at $625^{\circ} \mathrm{C}$ for $1 \mathrm{~min}$.

tion curve is observed because the enhancement of the anisotropy of the hard phase at low temperatures results in a significantly decrease of exchange length. This means that the exchange fields from the HM grains cannot completely cover the SM grains in the nearest-neighbor regions of the latter, and thus the magnetization reversal easily nucleates in the free region of the SM grains.

Because the saturation magnetization of $\mathrm{Fe}_{65} \mathrm{Co}_{35}$ alloy is higher than that of pure $\mathrm{Fe}$, the $\mathrm{Fe}_{65} \mathrm{Co}_{35}$ alloy is also chosen as the SM layer component of the multilayer films. Room-temperature hysteresis loops of $\operatorname{Ti}(30 \mathrm{~nm})$ buffered multilayer films with different thicknesses of HM and SM $\mathrm{Fe}_{65} \mathrm{Co}_{35}$ layers on a $\mathrm{Si}$ substrate annealed at $600^{\circ} \mathrm{C}$ for 5 min are given in Fig. 5, where sample 1: $\operatorname{Ti}(30 \mathrm{~nm}) /[\mathrm{HM}(18$ $\mathrm{nm}) \mathrm{FeCo}(9 \mathrm{~nm})] \times 20 / \mathrm{Ti}(30 \mathrm{~nm}) /(\mathrm{Si}$ substrate $)$, sample 2 : $\mathrm{Ti}(30 \mathrm{~nm}) /[\mathrm{HM}(15 \mathrm{~nm}) \mathrm{FeCo}(7.5 \mathrm{~nm})] \times 20 / \mathrm{Ti}(30 \mathrm{~nm}) /(\mathrm{Si}$ substrate $)$, and sample 3: $\mathrm{Ti}(30 \mathrm{~nm}) /[\mathrm{HM}(20 \mathrm{~nm}) \mathrm{FeCo}(10$ $\mathrm{nm})] \times 20 / \mathrm{Ti}(30 \mathrm{~nm}) /(\mathrm{Si}$ substrate $)$, respectively. It can be seen that all of the remanences and coercive forces of the multilayer films are higher and lower than that of the single layer film, respectively. Although the ratio of the thicknesses of hard and soft layers is same for the three samples, their effects on magnetic properties of the multilayer films are very different. Particularly in sample 3 , the hard and soft layers are so thick that the squareness of the hysteresis loop is relatively small. Because the ratio of the thicknesses of the

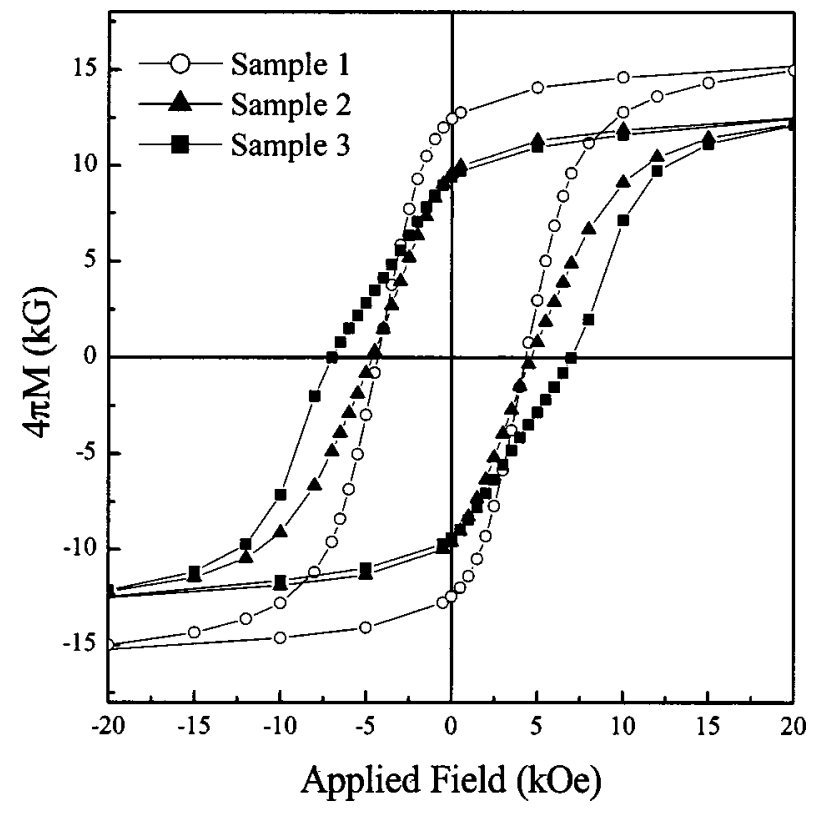

FIG. 5. Room-temperature hysteresis loops of $\mathrm{Ti}(30 \mathrm{~nm})$ buffered multilayer films with different thicknesses of $\mathrm{HM}$ and $\mathrm{SM}=\mathrm{Fe}_{65} \mathrm{Co}_{35}$ layers on $\mathrm{Si}$ substrate annealed at $600{ }^{\circ} \mathrm{C}$ for $5 \mathrm{~min}$, where sample 1: Ti(30 nm)/[HM(18 $\mathrm{nm}) \mathrm{FeCo}(9 \mathrm{~nm})] \times 20 / \mathrm{Ti}(30 \mathrm{~nm}) /(\mathrm{Si}$ substrate $)$, sample $2: \mathrm{Ti}(30 \mathrm{~nm}) /[\mathrm{HM}(15$ $\mathrm{nm}) \mathrm{FeCo}(7.5 \mathrm{~nm})] \times 20 / \mathrm{Ti}(30 \mathrm{~nm}) /(\mathrm{Si}$ substrate $)$, and sample 3: Ti(30 nm)/ $[\mathrm{HM}(20 \mathrm{~nm}) \mathrm{FeCo}(10 \mathrm{~nm})] \times 20 / \mathrm{Ti}(30 \mathrm{~nm}) /($ Si substrate $)$.

hard and soft layers is constrained, the mutually dispersed soft and hard phases formed in the multilayer film after annealing may result in incomplete exchange coupling between some hard and soft nanograins in the multilayer films. The maximum energy product of $14.6 \mathrm{MGOe}$ is achieved in $\mathrm{Ti}(30$ $\mathrm{nm}) /[\mathrm{HM}(18 \mathrm{~nm}) \mathrm{Fe}(9 \mathrm{~nm})] \times 20 / \mathrm{Ti}(30 \mathrm{~nm}) /(\mathrm{Si}$ substrate $)$ multilayer film. It is concluded that the proper thickness of hard and soft layers is necessary for the multilayer films to have the complete exchange coupling.

\section{ACKNOWLEDGMENTS}

This work has been supported by the U.S. NSF under Grant No. INT-9812082, DOE, AFOSR, DARPA/ARO, and the National Natural Science Foundation of China under Project Nos. 50071062 and 59725103, and the National 863 Project under Grant No. 2002AA302603.

${ }^{1}$ I. A. Al-Omari and D. J. Sellmyer, Phys. Rev. B 52, 3441 (1995).

${ }^{2}$ J. P. Liu, Y. Liu, R. Skomski, and D. J. Sellmyer, IEEE Trans. Magn. 35, 3241 (1999).

${ }^{3}$ M. Shindo and M. Ishizone, J. Appl. Phys. 81, 4444 (1997).

${ }^{4}$ S. Parhofer, J. Wecker, C. Kuhrt, and G. Gieres, IEEE Trans. Magn. 32, 4437 (1996).

${ }^{5}$ S. Parhofer, G. Gieres, J. Wecker, and L. Schultz, J. Magn. Magn. Mater. 163, 32 (1996).

${ }^{6}$ C. J. Yang and S. W. Kim, J. Magn. Magn. Mater. 202, 311 (1999).

${ }^{7}$ W. Liu, Z. D. Zhang, J. P. Liu, X. Z. Li, X. K. Sun, and D. J. Sellmyer, J. Appl. Phys. 91, 7890 (2002). 